\title{
Orexin A regulates plasma insulin and leptin levels in a time-dependent manner following a glucose load in mice
}

\author{
Jae-Hyung Park ${ }^{1,2}$ • Hae-Min Shim ${ }^{1}$ - Ann-Yae Na ${ }^{1}$ Jae-Hoon Bae ${ }^{1}$. \\ Seung-Soon Im $^{1,2}$ • Dae-Kyu Song ${ }^{1,2}$
}

Received: 15 February 2015 / Accepted: 13 March 2015 /Published online: 28 March 2015

(C) Springer-Verlag Berlin Heidelberg 2015

\begin{abstract}
Aims/hypothesis Orexin A (OXA) is a neuropeptide implicated in the regulation of arousal status and energy metabolism. Orexin receptors are expressed not only in the central nervous system but also in the pancreas and adipose tissue. However, little is known about the physiological function of orexins. This study investigated the role of exogenous OXA in blood glucose control after glucose load in mice. In addition, the effect of OXA on insulin secretion was also identified in mouse pancreatic beta cells.

Methods Insulin secretion and intracellular $\mathrm{Ca}^{2+}$ levels were measured in perifused mouse islets. To investigate the effects of exogenous OXA on blood glucose levels in vivo, intraperitoneal glucose tolerance tests were performed after a subcutaneous injection of OXA in normal and high-fat diet-induced diabetic mice.

Results OXA significantly potentiated glucose-stimulated insulin secretion in vitro, which increased intracellular $\mathrm{Ca}^{2+}$ levels, mainly through adenylate cyclase and ryanodine receptor activation. This $\mathrm{Ca}^{2+}$-dependent insulinotropic effect of OXA was blocked in Epac2 (Rapgef4)-deficient beta cells. After a glucose load in mice, exogenous OXA decreased blood glucose levels, compared with the control, by enhancing plasma insulin and decreasing plasma glucagon levels. Additionally, OXA caused
\end{abstract}

Dae-Kyu Song

dksong@kmu.ac.kr

1 Department of Physiology, Keimyung University School of Medicine, 1095 Dalgubeoldae-Ro, Dalseo-Gu, Daegu 704-701, South Korea

2 Obesity-Mediated Disease Research Center, Keimyung University School of Medicine, Daegu, South Korea a delayed increase in plasma leptin levels, resulting in lower plasma insulin levels when blood glucose levels fell to baseline. Conclusions/interpretation These results suggest that OXA might be a critical regulator of insulin, glucagon and leptin secretion in response to glucose. Thus, exogenous OXA might have therapeutic potential in improving blood glucose control in patients with type 2 diabetes.

Keywords Epac2 - Glucagon · Insulin secretion · Leptin · Orexin A · Rapgef4 · Type 2 diabetes

\begin{tabular}{|c|c|}
\hline \multicolumn{2}{|c|}{ Abbreviations } \\
\hline $\mathrm{AC}$ & Adenylate cyclase \\
\hline BFA & Brefeldin-A \\
\hline$\left[\mathrm{Ca}^{2+}\right]_{\mathrm{i}}$ & Intracellular calcium concentration \\
\hline EPAC & Exchange protein activated by cAMP \\
\hline GSIS & Glucose-stimulated insulin secretion \\
\hline HFD & High-fat diet \\
\hline HID & HFD-induced diabetic \\
\hline IPGTT & Intraperitoneal glucose tolerance test \\
\hline $\mathrm{IP}_{3} \mathrm{R}$ & $\operatorname{Ins}(1,4,5) \mathrm{P}_{3}$ receptor \\
\hline KRPH & Krebs-Ringer phosphate-HEPES \\
\hline OXA & Orexin A \\
\hline OXR & Orexin receptor \\
\hline PKA & Protein kinase $\mathrm{A}$ \\
\hline $\mathrm{PKC}$ & Protein kinase $\mathrm{C}$ \\
\hline PLC & Phospholipase C \\
\hline RyR & Ryanodine receptor \\
\hline
\end{tabular}

\section{Introduction}

Orexin A (OXA) and orexin B are hypothalamic neuropeptides implicated in the regulation of appetite and arousal status 
in the central nervous system [1]. Narcolepsy is associated with a decrease in the expression of hypothalamic orexin, compared with healthy controls [2], and is also associated with obesity and type 2 diabetes [3-6]. In addition, hypothalamic prepro-orexin mRNA levels are reduced in genetically obese $o b / o b$ and $d b / d b$ mice [7], and the deletion of orexin induces obesity and insulin resistance in mice [8]. These observations suggest that orexins play a role in the regulation of glucose homeostasis and energy metabolism.

Orexins interact with two G-protein-coupled receptor subtypes: orexin receptor 1 (OXR1) and OXR2 [1]. OXRs have been demonstrated not only in central neurons but also in some peripheral endocrine cells. Recent studies have demonstrated that OXR1 is expressed in the pancreatic alpha and beta cells of pigs, rats and mice [9-11] and in human and rat adipocytes $[12,13]$. Therefore, it is likely that orexins contribute to important endocrine functions.

A number of studies have reported the effects of OXA on insulin secretion and blood glucose levels in vivo and in vitro. In the fasting state, OXA potently inhibits glucagon secretion in perfused rat pancreas [11] and rats in vivo [14]. Consistently, OXA decreases blood glucose levels in fasting mice [15]. However, conflicting findings have been reported on the effect of OXA on insulin secretion in the fasting state in vivo [14-17]. A recent study demonstrated that OXA potentiates glucose-stimulated insulin secretion (GSIS) in perfused rat pancreas [11]. However, little is known about the mechanism of OXA's action in GSIS and the role of OXA in the regulation of blood glucose levels after a glucose load.

Leptin is an adipokine that affects insulin secretion and potently inhibits food consumption [18], in contrast to OXA, which is known to stimulate food intake at the level of the central nervous system $[19,20]$. Moreover, leptin potently inhibits insulin secretion [21-23] whereas OXA exerts the opposite effect [11]. These findings suggest that leptin and orexins are strongly correlated with each other and that they have counteracting roles in the regulation of appetite and plasma insulin levels.

Therefore, we investigated the role of OXA, which may act in concert with insulin and leptin, in the regulation of blood glucose levels after a glucose load in mice. In addition, we also examined the effect of OXA on GSIS, as well as the underlying mechanisms, in pancreatic beta cells.

\section{Methods}

Materials FBS and RPMI 1640 medium were purchased from Life Technologies (Carlsbad, CA, USA). OXA peptides, SB334867, JNJ10397049, U73122 and GF109203X were from Torcris Bioscience (Bristol, UK). H-89, xestospongin $\mathrm{C}$ and dantrolene sodium were from Cayman Chemical (Ann Arbor, MI, USA). MDL12330A was purchased from
Biomol (Plymouth Meeting, PA, USA). All other chemicals were obtained from Sigma-Aldrich (St Louis, MO, USA).

Experimental animals C57BL/6 (wild-type; WT) male mice were purchased from Jung-Ang Experimental Animals (Seoul, Korea). Epac2 knockout (KO) mice were a kind gift from S. Seino (Kobe University Graduate School of Medicine, Kobe, Japan). The Epac2 KO mice were generated by placing tandemly oriented loxP sites around a $1.3 \mathrm{~kb}$ DNA fragment that contained a portion of exon 1 and intron 1 from the mouse Epac2 gene; the fragment was subsequently removed using Cre recombinase. The lack of Epac2 expression in the pancreatic islets of the Epac2 KO mice was confirmed using an RTPCR analysis (data not shown). The mice were housed under a daily $12 \mathrm{~h}$ light-dark cycle and fed on a commercial normal chow diet (Research Diet, New Brunswick, NJ, USA) with $10 \%$ of energy from fat, $70 \%$ from carbohydrate and $20 \%$ from protein. The Keimyung University Institutional Ethics Committee (Daegu, Korea) approved all animal experiments (KM-2013-75).

High-fat diet studies To induce a model of type 2 diabetes, 5week-old C57BL/6 mice were fed a high-fat diet (HFD) (Research Diet) with $60 \%$ of energy from fat, $20 \%$ from carbohydrate, $20 \%$ from protein, for 8 weeks.

Intraperitoneal glucose tolerance test An intraperitoneal glucose tolerance test (IPGTT) was performed on normal or HFD-induced diabetic (HID) mice. On test days, the mice were fasted for $12 \mathrm{~h}$ and then given a subcutaneous injection of OXA $(16 \mathrm{nmol} / \mathrm{kg})$ or $0.2 \mathrm{ml}$ of the saline vehicle $(154 \mathrm{mmol} / 1 \mathrm{NaCl})$. A subcutaneous administration was chosen to achieve a slow rate of peptide absorption. After $30 \mathrm{~min}$, the mice were given an intraperitoneal injection of glucose $(500 \mathrm{mg} / \mathrm{kg}$ ). Blood glucose levels were measured from tail blood samples collected at $0,15,30,60,90,120,180$ and 240 min after the glucose treatment using the Glucocard Test Strip II (Arkray, Kyoto, Japan). Plasma glucagon, insulin, leptin and OXA levels were measured from orbital venous plexus blood samples using the ultrasensitive glucagon (Biovision, Milpitas, CA, USA), ultrasensitive insulin (Mercodia, Uppsala, Sweden) and leptin (Raybiotech, Norcross, GA, USA) ELISA kits and OXA (Phoenix Pharmaceuticals, Burlingame, CA, USA) chemiluminescent ELISA kit, respectively.

Isolation of mouse pancreatic islets Mouse pancreatic islets were isolated using a collagenase digestion technique. To collect dispersed islet cells, the islets were incubated in $1 \mathrm{ml}$ of Accutase solution (Innovative Cell Technologies, San Diego, CA, USA) for $15 \mathrm{~min}$ at $37^{\circ} \mathrm{C}$, and the cells were pipetted up and down gently 15-20 times to promote dissociation. The islets and dispersed islet cells were incubated in RPMI 1640 medium containing $5.6 \mathrm{mmol} / \mathrm{l}$ glucose and $10 \% \mathrm{FBS}$ within a 
humidified incubator at $37^{\circ} \mathrm{C}$ with $5 \% \mathrm{CO}_{2}$ for $12 \mathrm{~h}$. The dispersed islet cells were stained with insulin antibody to confirm the purity of beta cells. The beta cells were used for the measurement of intracellular $\mathrm{Ca}^{2+}$ concentration $\left(\left[\mathrm{Ca}^{2+}\right]_{\mathrm{i}}\right)$.

Western blot analysis The islet homogenates were subjected to SDS-PAGE and immunoblotted with anti-EPAC2 (Cell Signaling, Danvers, MA, USA), anti-OXR1 (Abcam, Cambridge, UK), anti-OXR2 (Abcam), anti-insulin (Santa Cruz Biotechnology, Santa Cruz, CA, USA) and anti-beta actin (Sigma-Aldrich) antibodies. The immunoreactive bands were visualised using a horseradish peroxidase-conjugated secondary antibody (Abcam) and enhanced chemiluminescence (Amersham Biosciences, Little Chalfont, UK). The experiments were repeated at least three times.

Measurement of static insulin secretion Static insulin secretion in the islets was measured using batch incubations. Ten size-matched islets were incubated in independent batches. The islets were incubated for $30 \mathrm{~min}$ at $37^{\circ} \mathrm{C}$ in Krebs-Ringer phosphate-HEPES (KRPH) buffer $(10 \mathrm{mmol} / 1$ phosphate buffer [pH 7.4], $1 \mathrm{mmol} / 1 \mathrm{MgSO}_{4}, 1 \mathrm{mmol} / 1 \mathrm{CaCl}_{2}$, $136 \mathrm{mmol} / \mathrm{l} \mathrm{NaCl}, 4.7 \mathrm{mmol} / \mathrm{l} \mathrm{KCl}$ and $10 \mathrm{mmol} / \mathrm{l}$ HEPES [pH 7.6]) containing $0.2 \% \mathrm{BSA}$ and $2.8 \mathrm{mmol} / \mathrm{l}$ glucose. The islets were stimulated with $16.7 \mathrm{mmol} / 1$ glucose for $30 \mathrm{~min}$, with or without $10 \mathrm{nmol} / \mathrm{l} \mathrm{OXA}$. After the incubation period, aliquots of the medium were collected. The supernatant fractions $(200 \mu \mathrm{l})$ were collected and stored at $-20^{\circ} \mathrm{C}$ for subsequent analysis.

Perifusion experiment Dynamic insulin secretion in perifusates was measured using an automated perifusion system. Briefly, a low-pulsatility peristaltic pump pushed the $\mathrm{KRPH}$ buffer containing $2.8 \mathrm{mmol} / \mathrm{l}$ glucose at a perifusion rate of $100 \mu \mathrm{l} / \mathrm{min}$ through a perifusion chamber (Biorep Technologies, Miami, FL, USA) containing 100 pancreatic islets immobilised in Bio-Gel P-4 Gel (Bio-Rad, Hercules, CA, USA). After a $30 \mathrm{~min}$ stabilisation period, the groups of islets were successively stimulated with $16.7 \mathrm{mmol} / \mathrm{l}$ glucose and $10 \mathrm{nmol} / 1 \mathrm{OXA}$. The perifusate was collected in an automatic fraction collector. The perifusion chamber containing the islets was kept at $37^{\circ} \mathrm{C}$ and the perifusate solutions were gassed with $95 \% \mathrm{O}_{2}$ and $5 \% \mathrm{CO}_{2}$ and maintained at $37^{\circ} \mathrm{C}$. Perifusates were collected every minute.

Measurement of cAMP content in pancreatic islets The cAMP content in the islets was measured according to the manufacturer's instructions for the cAMP enzyme immunoassay system (R\&D Systems, Minneapolis, MN, USA) in the presence of $16.7 \mathrm{mmol} / 1$ glucose. The islets were preincubated with an RPMI buffer containing $500 \mu \mathrm{mol} / 1$ isobutyl-methyl xanthine and $10 \mathrm{mmol} / 1 \mathrm{MgCl}_{2}$ at $37^{\circ} \mathrm{C}$ for $20 \mathrm{~min}$. The islets were then stimulated for $30 \mathrm{~min}$ at $37^{\circ} \mathrm{C}$ in a buffer that contained OXA $(10 \mathrm{nmol} / \mathrm{l})$ or forskolin $(10 \mu \mathrm{mol} /$ 1). The optical density for each treatment was determined immediately using a microplate reader at $405 \mathrm{~nm}$ with the wavelength correction set at $570 \mathrm{~nm}$. The cAMP levels were normalised to the protein concentration.

Measurement of intracellular ATP content in pancreatic islets The ATP content in the islets was measured according to the manufacturer's instructions for the luciferase assay (Invitrogen, Carlsbad, CA, USA). Twenty islets were used for ATP measurements in each batch. The islets were incubated for $2 \mathrm{~h}$ in KRPH buffer containing $2.8 \mathrm{mmol} / \mathrm{l}$ glucose and then exposed to $16.7 \mathrm{mmol} / \mathrm{l}$ glucose and $10 \mathrm{nmol} / 1 \mathrm{OXA}$ for $30 \mathrm{~min}$ at $37^{\circ} \mathrm{C}$. The ATP levels were normalised to the protein concentration.

Measurement of $\left[\mathrm{Ca}^{2+}\right]_{i}$ using confocal microscopy Changes in $\left[\mathrm{Ca}^{2+}\right]_{i}$ were determined using a confocal laser microscope (LSM 5 EXCITER; Carl Zeiss, Jena, Germany). The excitation and emission wavelengths for the detection of $\mathrm{Ca}^{2+}$ were 488 and $516 \mathrm{~nm}$, respectively. The fluorescence images were collected at intervals of $3 \mathrm{~s}$ and analysed using LSM5 software version 4.2 (Carl Zeiss). The chemical reagents were applied using a flow system with a flow rate of approximately $1 \mathrm{ml} / \mathrm{min}$ at $37^{\circ} \mathrm{C}$. The primary pancreatic beta cells were loaded with the $\mathrm{Ca}^{2+}$-sensitive dye fluo-4/acetoxymethyl ester ( $3 \mu \mathrm{mol} / 1$; Molecular Probes, Eugene, OR, USA) in a KRPH buffer containing $2.8 \mathrm{mmol} / \mathrm{l}$ glucose for $30 \mathrm{~min}$. The cells were then incubated for $20 \mathrm{~min}$ in a dye-free solution to enable the esterase cleavage of fluo-4/acetoxymethyl ester to liberate fluo-4. After the establishment of a stable baseline $\left[\mathrm{Ca}^{2+}\right]_{\mathrm{i}}$ level, the cells were stimulated with $16.7 \mathrm{mmol} / \mathrm{l}$ glucose for $5 \mathrm{~min}$, followed by $10 \mathrm{nmol} / \mathrm{l} \mathrm{OXA}$ for $5 \mathrm{~min}$. The results were plotted as the change in fluorescence intensity and the magnitude was calculated as the change in fluorescence intensity, expressed as a percentage of the basal fluorescence intensity $\left(\mathrm{F}_{0}\right)$.

Statistical analysis Results were expressed as the mean \pm SEM. SPSS version 20.0 (SPSS, Chicago, IL, USA) was used for statistical analyses. The AUC was calculated using Microcal Origin software version 9.1 (Northampton, MA, USA). Comparisons between the two groups were performed using a Student's two-tailed $t$ test. For comparisons involving more than two groups, the significance was tested using ANOVA with Bonferroni correction. Statistical significance was set at $p<0.05$.

\section{Results}

OXA potentiates GSIS through an OXR1/cAMP signalling pathway in mouse pancreatic islets We investigated 
the effect of OXA on GSIS and determined the expression of OXR1 in mouse pancreatic islets in vitro. Thus, by western blot analysis, we identified a single OXR1 band of $52 \mathrm{kDa}$ in protein lysates prepared from hand-picked and highly purified islets (Fig. 1a). In addition, OXA induced a dose-dependent increase in GSIS (Fig. 1b). Pretreatment with the specific OXR1 antagonist SB334867, phospholipase C (PLC) inhibitor U73122 or protein kinase C (PKC) inhibitor GF109203X blocked the stimulatory effect of OXA on GSIS, whereas pretreatment with the specific OXR2 antagonist JNJ10397049 had no such effect (Fig. 1d). Although OXA-mediated changes in cellular ATP levels were not observed (Fig. 1c), OXA augmented cellular cAMP levels compared with the control (Fig. 1e). Pretreatment with the OXR1 antagonist, PLC inhibitor, PKC inhibitor or adenylate cyclase (AC) inhibitor MDL12330A blocked the stimulatory effect of OXA on cAMP (Fig. 1e).

OXA potentiates glucose-stimulated $\left[\mathrm{Ca}^{2+}\right]_{i}$ increase via the activation of ryanodine receptors To investigate the downstream signalling mechanism following the OXAinduced cAMP increase, glucose-stimulated $\left[\mathrm{Ca}^{2+}\right]_{\mathrm{i}}$ changes were measured in the presence of various cAMP signalling pathway inhibitors in the primary beta cells. OXA further increased the $\left[\mathrm{Ca}^{2+}\right]_{\mathrm{i}}$ levels in response to high glucose (Fig. 2a). As shown in Fig. 2b, the stimulatory effect of
OXA on $\left[\mathrm{Ca}^{2+}\right]_{\mathrm{i}}$ was not observed in the presence of the PLC inhibitor, PKC inhibitor or AC inhibitor or in the presence of H-89 (a non-selective inhibitor of protein kinase A [PKA]) or brefeldin-A (BFA; a non-selective inhibitor of exchange protein activated by cAMP [EPAC]) [24, 25]. However, the involvement of EPAC signalling, compared with that of PKA, was more predominant for the stimulatory effect of OXA on the glucose-stimulated $\left[\mathrm{Ca}^{2+}\right]_{i}$ increase. Because the activation of the $\operatorname{Ins}(1,4,5) \mathrm{P}_{3}$ receptor $\left(\mathrm{IP}_{3} \mathrm{R}\right)$ in response to cAMP signalling is a PKA-dependent mechanism and the activation of ryanodine receptors (RyRs) is an EPACdependent mechanism [26, 27], we next investigated the effect of OXA on glucose-stimulated $\left[\mathrm{Ca}^{2+}\right]_{\mathrm{i}}$ increase in the presence of the $\mathrm{IP}_{3} \mathrm{R}$ antagonist xestospongin $\mathrm{C}$ and the RyR antagonist dantrolene sodium. The stimulatory effect of OXA on $\left[\mathrm{Ca}^{2+}\right]_{\mathrm{i}}$ was remarkably reduced not only in the presence of the RyR antagonist but also in the presence of the $\mathrm{IP}_{3} \mathrm{R}$ antagonist (Fig. 2c, d). However, the involvement of RyR signalling was more predominant than the involvement of $\mathrm{IP}_{3} \mathrm{R}$ signalling for the stimulatory effect of OXA on the $\left[\mathrm{Ca}^{2+}\right]_{\mathrm{i}}$ increase.

OXA enhances GSIS through a cAMP-EPAC2-RyR-dependent mechanism We next investigated the signalling mechanism for the stimulatory effect of OXA on GSIS in the presence of various inhibitors of the cAMP signalling pathway in the primary islets. As shown in Fig. 3, the

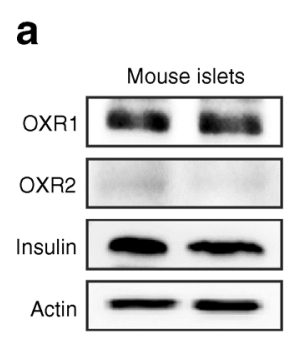

b
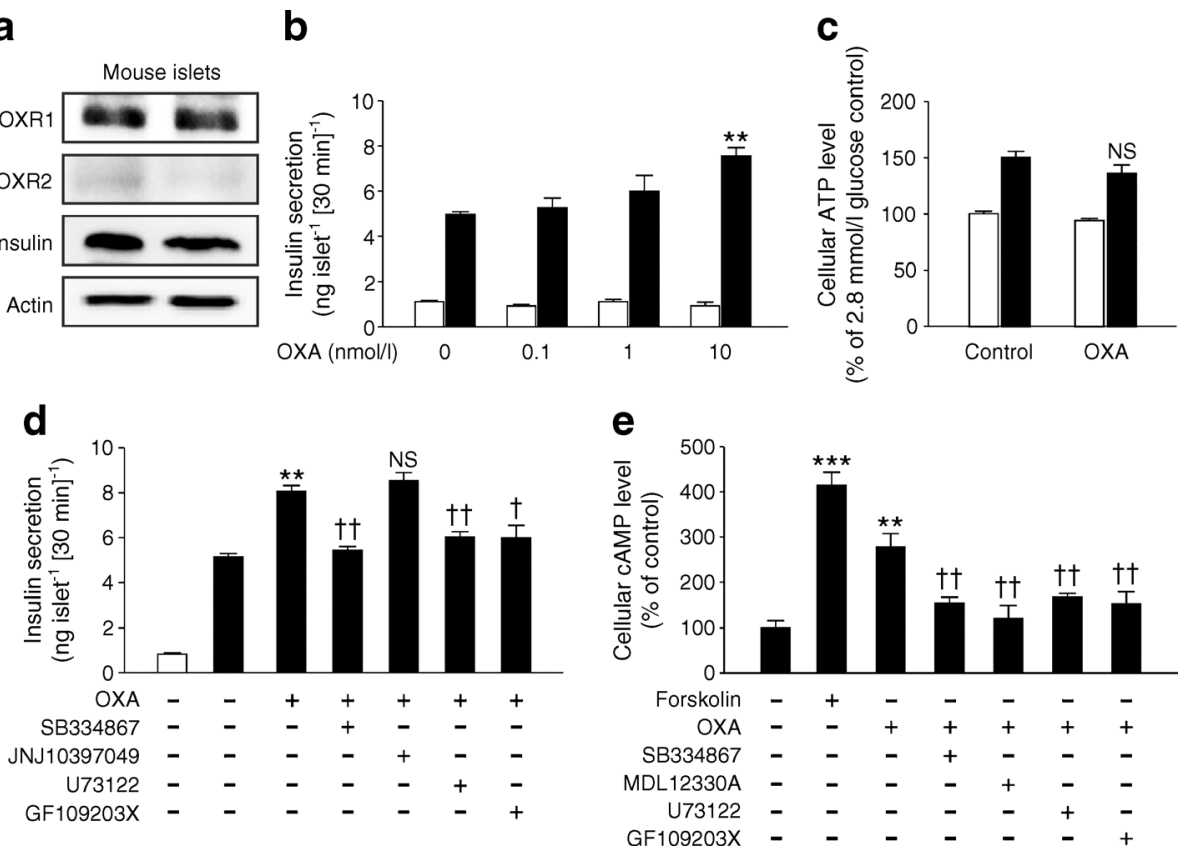

Fig. 1 Effect of OXA on GSIS in mouse pancreatic islets. (a) Detection of OXR1, OXR2 and insulin expression in protein lysates by western blots. (b) Dose-dependent effect of OXA on GSIS levels. (c) Effect of OXA (10 nmol/l) on cellular ATP levels. (d) Effect of OXA (10 nmol/1) on GSIS. The islets were pretreated with SB334867 $(10 \mu \mathrm{mol} / 1)$, JNJ10397049 $(10 \mu \mathrm{mol} / 1)$, U73122 (5 $\mu \mathrm{mol} / \mathrm{l})$ or GF109203X $(0.3 \mu \mathrm{mol} / \mathrm{l})$ for $30 \mathrm{~min}$ prior to high-glucose stimulation. (e) Effect of

OXA on cellular cAMP levels. The islets were pretreated with SB334867, MDL12330A (10 $\mu \mathrm{mol} / \mathrm{l}), \mathrm{U} 73122$ or GF109203X for $20 \mathrm{~min}$. The values represent the mean $\pm \mathrm{SEM}, n=6 .{ }^{* *} p<0.01$ and ${ }^{* * *} p<0.001$ vs islets treated with $16.7 \mathrm{mmol} / 1$ glucose alone; ${ }^{\dagger} p<0.05$ and ${ }^{\dagger \dagger} p<0.01 \mathrm{vs}$ islets treated with OXA alone. White bars, $2.8 \mathrm{mmol} / 1$ glucose; black bars, $16.7 \mathrm{mmol} / 1$ glucose 
a
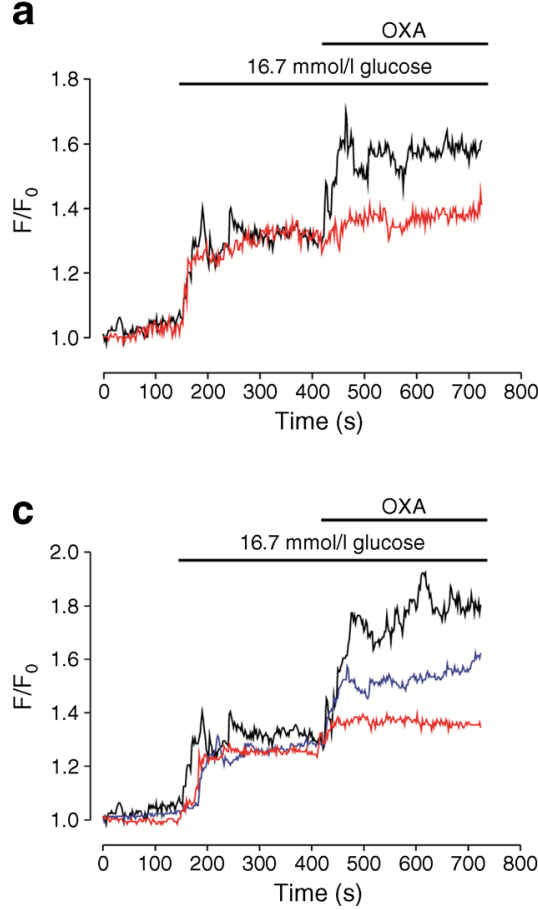

Fig. 2 Effect of OXA on glucose-stimulated $\left[\mathrm{Ca}^{2+}\right]_{\mathrm{i}}$ increase in pancreatic beta cells. Cells were stimulated with $16.7 \mathrm{mmol} / 1$ glucose for $5 \mathrm{~min}$, followed by $10 \mathrm{nmol} / 1$ OXA for $5 \mathrm{~min}$. (a) Representative data from six independent experiments are shown. Red line, control; black line, OXA. (b) Cells were pre-incubated for $30 \mathrm{~min}$ with the following inhibitors:

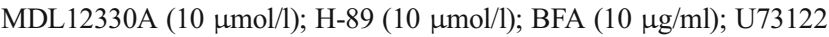
(5 $\mu \mathrm{mol} / 1)$; or GF109203X $(0.3 \mu \mathrm{mol} / 1)$. The AUC is depicted as the percentage of the values in the presence of $16.7 \mathrm{mmol} / \mathrm{l}$ glucose alone. (c) Cells were pre-incubated for $30 \mathrm{~min}$ with xestospongin $\mathrm{C}(10 \mu \mathrm{mol} / \mathrm{l})$

stimulatory effect of OXA on GSIS was not observed in the presence of the OXR1 antagonist, AC inhibitor, PKA inhibitor, EPAC inhibitor or RyR antagonist. However, the involvement of EPAC-RyR signalling was found to be more

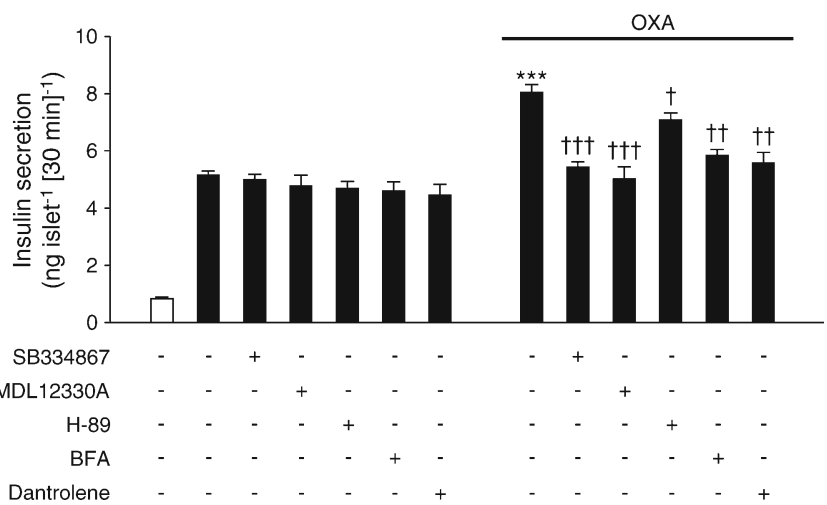

Fig. 3 Involvement of cAMP-EPAC-RyR signalling in OXA-potentiated GSIS. Islets were incubated for $30 \mathrm{~min}$ with the following inhibitors: SB334867 $(10 \mu \mathrm{mol} / \mathrm{l})$; MDL12330A $(10 \mu \mathrm{mol} / \mathrm{l})$; H-89 $(10 \mu \mathrm{mol} / \mathrm{l})$; BFA $(10 \mu \mathrm{g} / \mathrm{ml})$ or dantrolene sodium $(10 \mu \mathrm{mol} / \mathrm{l})$. The values represent the mean \pm SEM, $n=10$. ${ }^{* * *} p<0.001$ vs islets treated with $16.7 \mathrm{mmol} / 1$ glucose alone; ${ }^{\dagger} p<0.05,{ }^{\dagger \dagger} p<0.01$ and ${ }^{\dagger \dagger} p<0.001$ vs islets treated with OXA alone. White bar, $2.8 \mathrm{mmol} / 1$ glucose; black bars, $16.7 \mathrm{mmol} / 1$ glucose b
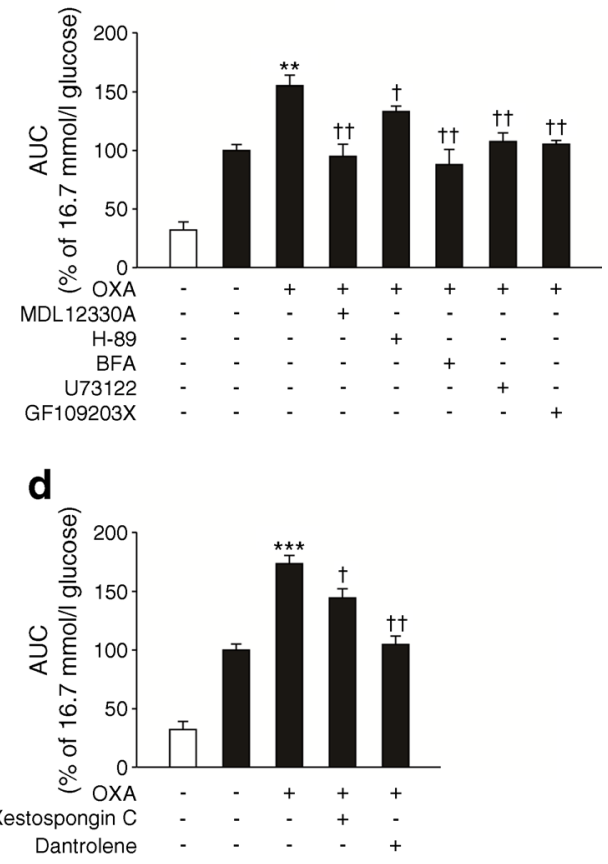

or dantrolene sodium $(10 \mu \mathrm{mol} / \mathrm{l})$. Representative data from six independent experiments are shown. Black line, OXA control; blue line, xestospongin C; red line, dantrolene sodium. (d) The AUC is depicted as the percentage of the values in the presence of $16.7 \mathrm{mmol} / \mathrm{l}$ glucose alone. The values represent the mean \pm SEM, $n=6-8 .{ }^{* *} p<0.01$ and $* * * p<0.001$ vs cells treated with $16.7 \mathrm{mmol} / 1$ glucose alone; ${ }^{\dagger} p<0.05$ and ${ }^{\dagger} p<0.01$ vs cells treated with OXA alone. White bars, $2.8 \mathrm{mmol} / 1$ glucose; black bars, $16.7 \mathrm{mmol} / \mathrm{l}$ glucose

predominant than that of PKA signalling for the stimulatory effect of OXA on GSIS. To confirm the involvement of the EPAC signalling pathway in the stimulatory effect of OXA on GSIS, Epac2 KO mouse islets were used (Fig. 4a). OXAinduced cAMP increase was not reduced in Epac2-deficient islets (Fig. 4b). As expected, OXA-induced increases in $\left[\mathrm{Ca}^{2+}\right]_{\mathrm{i}}$ and GSIS (Fig. 4c, d) were dramatically reduced in Epac2-deficient beta cells and islets, respectively. Next, the role of OXA in the insulin secretion phase was investigated using perifused mouse islets. OXA strongly increased both first and second phases of GSIS (Fig. 4e). Moreover, the OXA-induced increase during both phases of insulin secretion was dramatically reduced in Epac2 $\mathrm{KO}$ mouse islets (Fig. 4f).

Exogenous OXA increases plasma insulin and leptin levels in a time-dependent manner following a glucose load in normal mice To investigate the effect of exogenous OXA on blood glucose levels in vivo, an extended IPGTT (over $4 \mathrm{~h}$ ) was performed following a subcutaneous injection of OXA in normal mice. The plasma levels of OXA increased approximately $30 \mathrm{~min}$ after OXA injection (Fig. 5a). After the glucose load, the OXA-treated group showed significantly decreased blood glucose levels compared with the control 
Fig. 4 Effect of OXA on GSIS in

Epac2 KO mouse islets. (a)

Western blot analysis of EPAC2

protein in WT or Epac2 KO

mouse islets. (b) Effect of OXA

on cellular cAMP levels. (c)

Effect of OXA on glucose-

stimulated $\left[\mathrm{Ca}^{2+}\right]_{\mathrm{i}}$ levels.

Representative data from three

independent experiments are

shown. Black line, WT; red line,

Epac2 KO. (d) Effect of OXA on

GSIS in mouse islets. White bars,

$2.8 \mathrm{mmol} / \mathrm{l}$ glucose; black bars,

$16.7 \mathrm{mmol} / 1$ glucose. (e, f) In the

WT (e) or Epac2 KO (f) mouse

perifused islets, glucose

concentration was increased from

2.8 to $16.7 \mathrm{mmol} / \mathrm{l}$ and

maintained for $20 \mathrm{~min}$. Either

OXA (white circles) or the

vehicle (black circles) was

administered with $16.7 \mathrm{mmol} / 1$

glucose stimulation. The values

represent the mean \pm SEM, $n=10$.

${ }^{*} p<0.05, * * p<0.01$ and

$* * * p<0.001$ vs islets treated with

$16.7 \mathrm{mmol} / \mathrm{l}$ glucose alone a

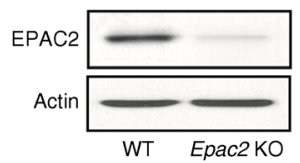

C

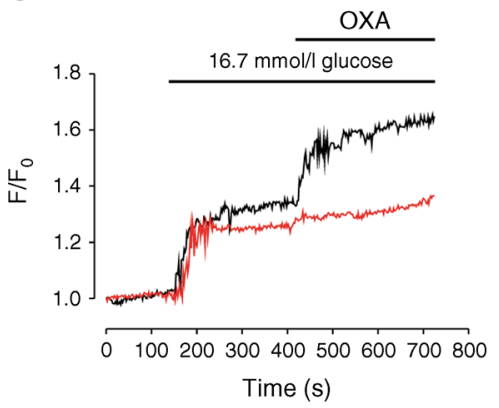

e

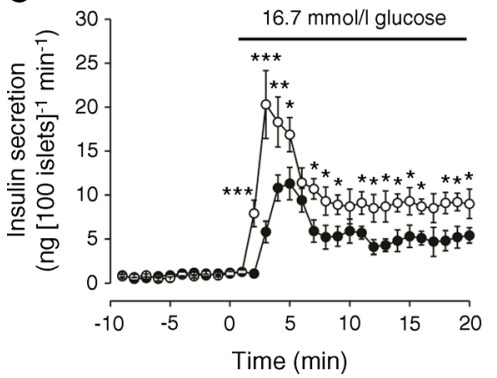

d
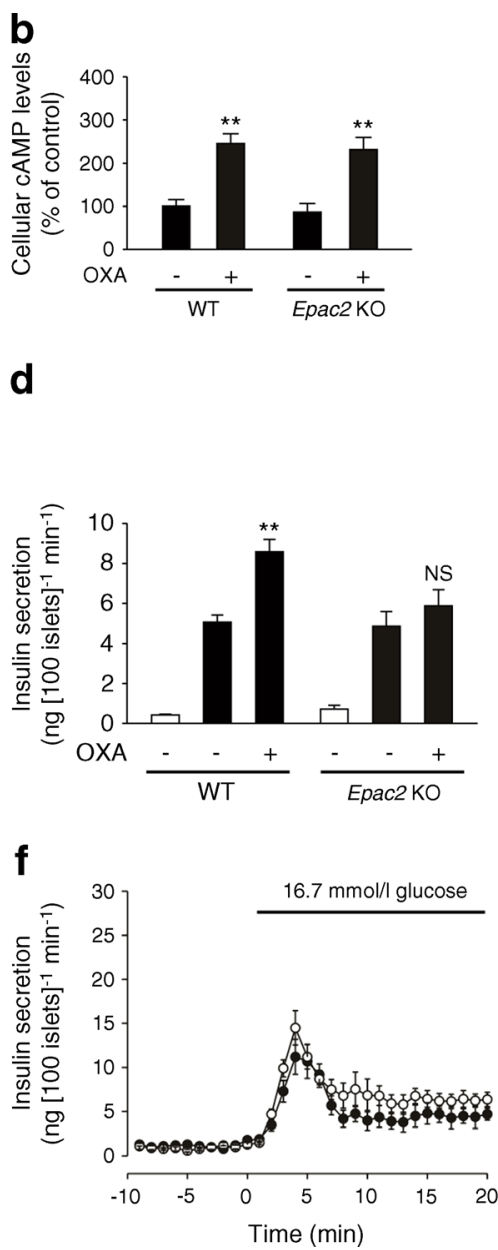

a

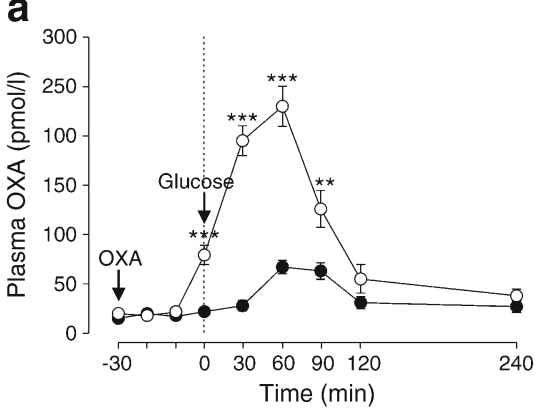

C

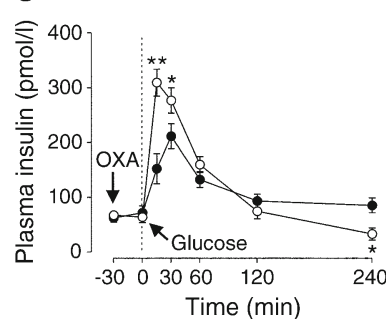

Fig. 5 Effect of exogenous OXA on blood glucose, plasma insulin, glucagon and leptin levels after a glucose load in normal mice. C57BL/6 mice (12 weeks old) were given a subcutaneous injection of $2 \mathrm{ml}$ of vehicle (black circles) or $16 \mathrm{nmol} / \mathrm{kg}$ OXA (white circles). After $30 \mathrm{~min}$, the mice were given an intraperitoneal injection of glucose b
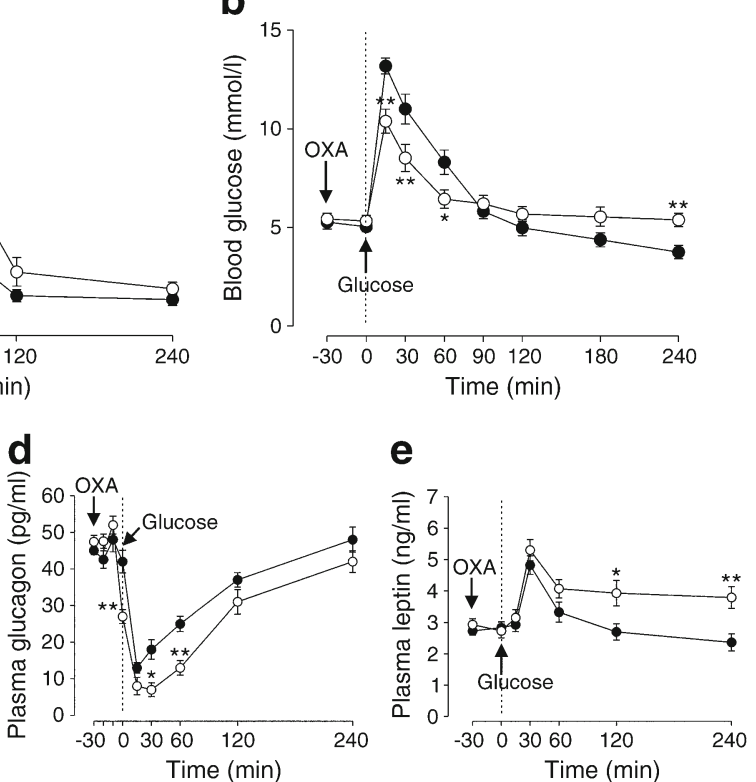

$(500 \mathrm{mg} / \mathrm{kg})$. Plasma OXA (a), blood glucose (b) and plasma insulin (c), glucagon (d) and leptin (e) levels were measured for $4 \mathrm{~h}$ after the glucose load. The values represent the mean \pm SEM, $n=8$. ${ }^{*} p<0.05$, $* * p<0.01$ and $* * * p<0.001$ vs control group treated with the vehicle at each time point 


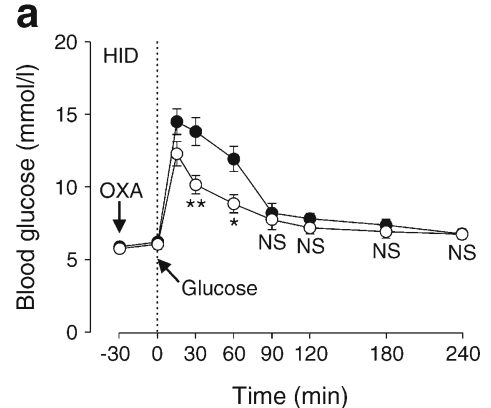

Fig. 6 Effect of exogenous OXA on blood glucose, plasma insulin and leptin levels after a glucose load in HID mice. After 8 weeks of HFD, mice were given a subcutaneous injection of $2 \mathrm{ml}$ of vehicle (black circles) or $16 \mathrm{nmol} / \mathrm{kg}$ OXA (white circles). After $30 \mathrm{~min}$, the mice were

(Fig. 5b), which was correlated with an increase in plasma insulin levels (Fig. 5c) and a reduction in plasma glucagon levels (Fig. 5d) compared with the control. Interestingly, exogenous OXA also increased plasma leptin levels significantly compared with the control at 2-4 $\mathrm{h}$ after the glucose load (Fig. 5e); this leptin response was rather delayed and sustained compared with the insulin increase and glucagon decrease. Consistent with this, at $4 \mathrm{~h}$ after the glucose load, plasma insulin and blood glucose levels in the OXA-treated group were significantly lower and higher, respectively, compared with the control.

\section{Exogenous OXA improves glucose tolerance in HID mice} by potentiating insulin and leptin release To evaluate the therapeutic potential of exogenous OXA in type 2 diabetes, an

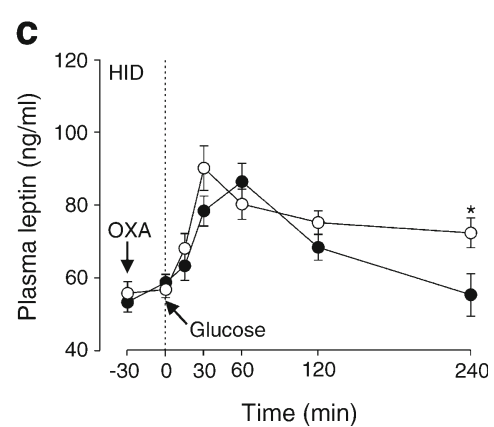

given an intraperitoneal injection of glucose $(300 \mathrm{mg} / \mathrm{kg})$. Blood glucose (a) and plasma insulin (b) and leptin (c) levels were measured for $4 \mathrm{~h}$ after the glucose load. The values represent the mean \pm SEM, $n=8$. ${ }^{*} p<0.05$ and ${ }^{* *} p<0.01$ vs control group treated with the vehicle at each time point

extended IPGTT was also performed in vivo following a subcutaneous injection of OXA in HID mice. OXA-treated mice showed improved glucose tolerance compared with control diabetic mice (Fig. 6a). In addition, an OXA-induced timedependent potentiation of insulin and leptin secretion in response to high glucose was also observed in the diabetic mice (Fig. 6b, c).

\section{Discussion}

The principal finding of this study was that OXA potentiated GSIS both in vitro and in vivo. Our in vitro experiments demonstrated that OXA increased cAMP levels through its binding to OXR1, which in turn potentiated glucose-stimulated

Fig. 7 Proposed mechanism to explain the role of exogenous OXA in regulating blood glucose levels and the effects of OXA on insulin, glucagon and leptin secretion. ER, endoplasmic reticulum; $\mathrm{K}_{\mathrm{ATB}}$ ATP-sensitive $\mathrm{K}^{+}$; Mito, mitochondria; $\Delta \Psi$, membrane depolarisation; VDCC, voltage-dependent calcium channel

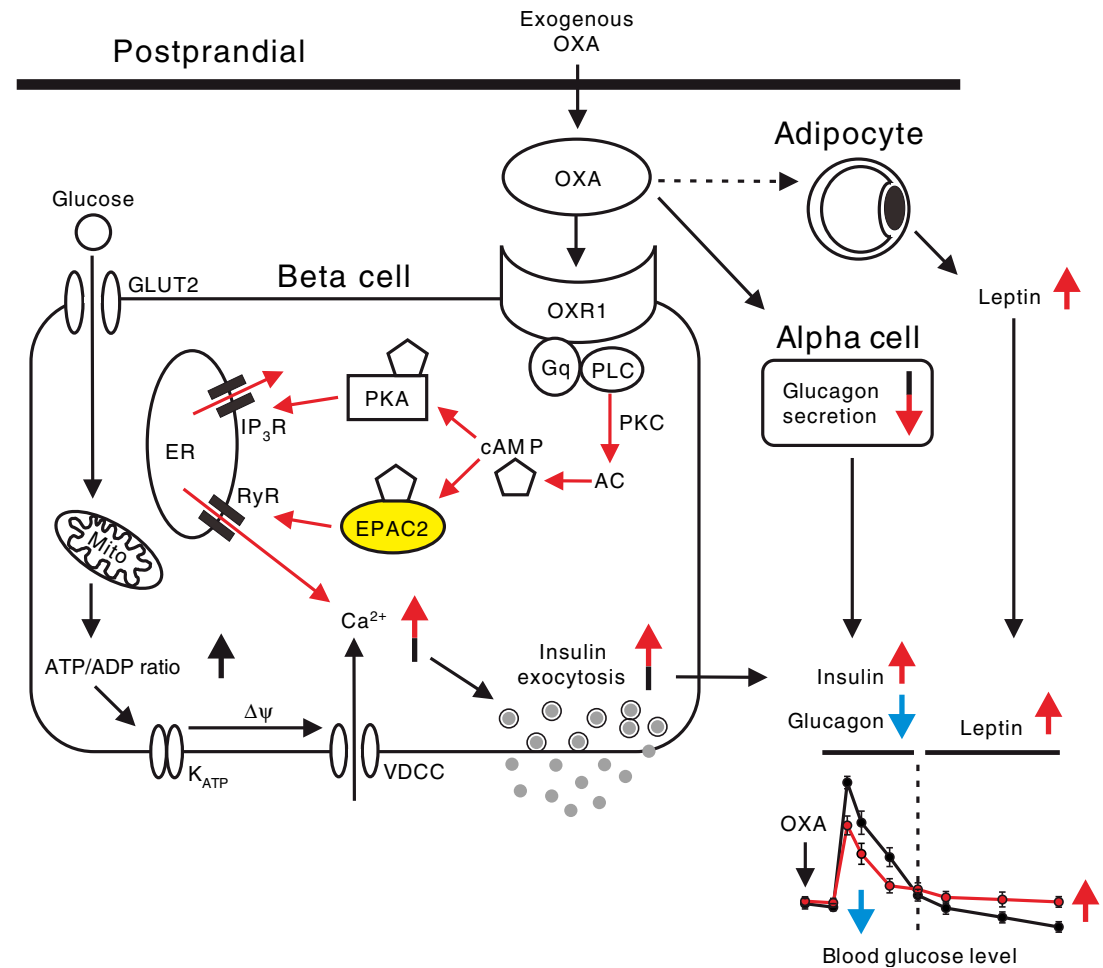


$\left[\mathrm{Ca}^{2+}\right]_{\mathrm{i}}$ increase via EPAC2 in mouse beta cells. The activated EPAC2 subsequently interacted with RyRs, which stimulated the release of $\mathrm{Ca}^{2+}$ from intracellular $\mathrm{Ca}^{2+}$ stores. This effect of OXA on the glucose-stimulated $\left[\mathrm{Ca}^{2+}\right]_{\mathrm{i}}$ increase potentiated GSIS. Moreover, our in vivo experiments demonstrated that exogenous OXA improved glucose tolerance via an increase in plasma insulin and leptin levels after a glucose load in mice, in addition to its effect of decreasing plasma glucagon levels [15]. Our proposed mechanism for the role of exogenous OXA in regulating blood glucose levels and its effects on insulin, glucagon and leptin secretion in beta cells is shown in Fig. 7.

Previous studies have demonstrated that OXR1 is clearly expressed in pancreatic islets and beta cells of pigs, rats and mice [9-11]. Here, we showed that OXA influenced insulin secretion in pancreatic islets through OXR1, but not OXR2. Of note, we did not detect OXR2 expression in mouse pancreatic islets. In addition, OXR1 has been shown to have a higher affinity for OXA [1]. In neuronal cells, OXR1 is coupled with the $\mathrm{G}_{\mathrm{q}}$ class of $\mathrm{G}$-proteins, resulting in the activation of PLC and the subsequent trigger of the phosphatidylinositol cascade [28]. Holmqvist et al [29] showed that OXA increases cellular cAMP levels through activation of PKC via $\mathrm{G}_{\mathrm{q}}$-mediated PLC stimulation in recombinant ovary cells. Consistent with these reports, the current study demonstrated that OXA increased the cAMP levels in pancreatic islets, which could be dependent on the $\mathrm{G}_{\mathrm{q}}-\mathrm{PLC}-\mathrm{PKC}$ signalling pathway.

The increased cAMP levels in beta cells most likely activate the downstream signalling of PKA [30] and EPAC2 [26, 31]. Consistent with these data, we found that the stimulatory effects of OXA on the glucose-stimulated $\left[\mathrm{Ca}^{2+}\right]_{\mathrm{i}}$ increase and insulin secretion were dependent on both PKA and EPAC2, although cAMP-EPAC2-RyR signalling was more predominant than cAMP-PKA signalling. Furthermore, OXA failed to potentiate GSIS in Epac2-deficient islets.

Exogenous OXA potently inhibits glucagon secretion in the fasting state $[11,14]$. However, little is known about the physiological roles of OXA in the fasting state. We demonstrated that plasma glucagon levels were decreased by exogenous OXA even in the fed state. Recently, Arafat et al [32] demonstrated that glucagon suppressed, whereas insulin stimulated, OXA secretion in humans. This report suggests that the physiological actions of OXA are suppressed by glucagon in the fasting state and activated by insulin in the fed state. Consistent with this hypothesis, the current study demonstrated that exogenous OXA improved glucose tolerance by increasing plasma insulin levels and decreasing plasma glucagon levels during the fed state.

As an additional novel finding, we also demonstrated that OXA employs leptin in response to high glucose: OXA caused a long-lasting increase in plasma leptin levels from $2 \mathrm{~h}$ after glucose load. Late-onset sustained leptin secretion by OXA can help to utilise fatty acids and prevent unexpected hypoglycaemia possibly via the inhibition of excessive insulin secretion [21-23]. Consistent with our data, Switonska et al [16] demonstrated that OXA significantly elevated leptin blood concentrations in fasted rats. However, additional studies are needed to evaluate the mechanism underlying the effect of OXA on leptin secretion in adipose tissue.

A reduction in plasma OXA levels has been identified in rat [13] and mouse [32] models of obesity and type 2 diabetes and in obese humans with type 2 diabetes [33]. Interestingly, we observed that exogenous OXA markedly improved glucose tolerance in HID mice via potentiation of insulin and leptin secretion. As a physiological regulator in the control of insulin, glucagon and leptin secretion, OXA might have therapeutic potential in patients with type 2 diabetes. However, additional studies are needed to evaluate the effect of exogenous OXA on blood glucose levels in the fasting state in vivo.

Acknowledgements We are grateful to H. C. Cho (Keimyung University School of Medicine) and Y. W. Kim (Yeungnam University School of Medicine, Daegu, Korea) for their helpful discussion on this study. We specially thank S. Seino (Kobe University Graduate School of Medicine, Kobe, Japan) for providing Epac2 KO mice.

Funding This study was supported by the Basic Science Research Program through the National Research Foundation of Korea (NRF) Grant funded by the Ministry of Education (NRF-2013R1A1A4A01008364) and by the Korean Government (MSIP) (NRF-2014R1A5A2010008).

Duality of interest The authors declare that there is no duality of interest associated with this manuscript.

Contribution statement JHP, HMS and AYN made substantial contributions to study conception and design, the acquisition, analysis and interpretation of data and the drafting of the article. JHB and SSI contributed to the study design and reviewed, edited and critically revised the manuscript. DKS made substantial contributions to study conception and design, the analysis and interpretation of data and revised this article critically for important intellectual content. All authors gave final approval of the current version to be published. JHP and DKS are responsible for the integrity of the work as a whole.

\section{References}

1. Sakurai T, Amemiya A, Ishii M et al (1998) Orexins and orexin receptors: a family of hypothalamic neuropeptides and $\mathrm{G}$ proteincoupled receptors that regulate feeding behavior. Cell 92:573-585

2. Higuchi S, Usui A, Murasaki M et al (2002) Plasma orexin-A is lower in patients with narcolepsy. Neurosci Lett 318:61-64

3. Honda Y, Doi Y, Ninomiya R, Ninomiya C (1986) Increased frequency of non-insulin-dependent diabetes mellitus among narcoleptic patients. Sleep 9:254-259

4. Schuld A, Hebebrand J, Geller F, Pollmacher T (2000) Increased body-mass index in patients with narcolepsy. Lancet 355:12741275

5. Nishino S, Ripley B, Overeem S et al (2001) Low cerebrospinal fluid hypocretin (Orexin) and altered energy homeostasis in human narcolepsy. Ann Neurol 50:381-388 
6. Beitinger PA, Fulda S, Dalal MA et al (2012) Glucose tolerance in patients with narcolepsy. Sleep 35:231-236

7. Yamamoto Y, Ueta Y, Date Y et al (1999) Down regulation of the prepro-orexin gene expression in genetically obese mice. Brain Res Mol Brain Res 65:14-22

8. Tsuneki H, Murata S, Anzawa Y et al (2008) Age-related insulin resistance in hypothalamus and peripheral tissues of orexin knockout mice. Diabetologia 51:657-667

9. Kirchgessner AL, Liu M (1999) Orexin synthesis and response in the gut. Neuron 24:941-951

10. Adeghate E, Fernandez-Cabezudo M, Hameed R et al (2010) Orexin-1 receptor co-localizes with pancreatic hormones in islet cells and modulates the outcome of streptozotocin-induced diabetes mellitus. PLoS One 5:e8587

11. Goncz E, Strowski MZ, Grotzinger C et al (2008) Orexin-A inhibits glucagon secretion and gene expression through a Foxo1dependent pathway. Endocrinology 149:1618-1626

12. Digby JE, Chen J, Tang JY, Lehnert H, Matthews RN, Randeva HS (2006) Orexin receptor expression in human adipose tissue: effects of orexin-A and orexin-B. J Endocrinol 191:129-136

13. Shen Y, Zhao Y, Zheng D, Chang X, Ju S, Guo L (2013) Effects of orexin A on GLUT4 expression and lipid content via MAPK signaling in 3T3-L1 adipocytes. J Steroid Biochem Mol Biol 138:376-383

14. Ehrstrom M, Naslund E, Levin F et al (2004) Pharmacokinetic profile of orexin A and effects on plasma insulin and glucagon in the rat. Regul Pept 119:209-212

15. Tsuneki H, Sugihara Y, Honda R, Wada T, Sasaoka T, Kimura I (2002) Reduction of blood glucose level by orexins in fasting normal and streptozotocin-diabetic mice. Eur J Pharmacol 448:245-252

16. Switonska MM, Kaczmarek P, Malendowicz LK, Nowak KW (2002) Orexins and adipoinsular axis function in the rat. Regul Pept 104:69-73

17. Nowak KW, Mackowiak P, Switonska MM, Fabis M, Malendowicz LK (2000) Acute orexin effects on insulin secretion in the rat: in vivo and in vitro studies. Life Sci 66:449-454

18. Seufert J (2004) Leptin effects on pancreatic $\beta$-cell gene expression and function. Diabetes 53(Suppl 1):S152-S158

19. Funahashi H, Hori T, Shimoda Y et al (2000) Morphological evidence for neural interactions between leptin and orexin in the hypothalamus. Regul Pept 92:31-35

20. Shiraishi T, Oomura Y, Sasaki K, Wayner MJ (2000) Effects of leptin and orexin-A on food intake and feeding related hypothalamic neurons. Physiol Behav 71:251-261
21. Kieffer TJ, Heller RS, Habener JF (1996) Leptin receptors expressed on pancreatic beta cells. Biochem Biophys Res Commun 224:522-527

22. Emilsson V, Liu YL, Cawthorne MA, Morton NM, Davenport M (1997) Expression of the functional leptin receptor mRNA in pancreatic islets and direct inhibitory action of leptin on insulin secretion. Diabetes 46:313-316

23. Nowak KW, Mackowiak P, Nogowski L, Szkudelski T, Malendowicz LK (1998) Acute leptin action on insulin blood level and liver insulin receptor in the rat. Life Sci 63:1347-1352

24. Ster J, de Bock F, Bertaso F et al (2009) Epac mediates PACAPdependent long-term depression in the hippocampus. J Physiol 587:101-113

25. Zhong N, Zucker RS (2005) cAMP acts on exchange protein activated by cAMP/cAMP-regulated guanine nucleotide exchange protein to regulate transmitter release at the crayfish neuromuscular junction. J Neurosci 25:208-214

26. Kang G, Joseph JW, Chepurny OG et al (2003) Epac-selective cAMP analog 8-pCPT-2'-O-Me-cAMP as a stimulus for $\mathrm{Ca}^{2+}$-induced $\mathrm{Ca}^{2+}$ release and exocytosis in pancreatic beta cells. J Biol Chem 278:8279-8285

27. Tsuboi T, da Silva Xavier G, Holz GG, Jouaville LS, Thomas AP, Rutter GA (2003) Glucagon-like peptide-1 mobilizes intracellular $\mathrm{Ca}^{2+}$ and stimulates mitochondrial ATP synthesis in pancreatic MIN6 beta cells. Biochem J 369:287-299

28. Zhu Y, Miwa Y, Yamanaka A et al (2003) Orexin receptor type-1 couples exclusively to pertussis toxin-insensitive G-proteins, while orexin receptor type- 2 couples to both pertussis toxin-sensitive and -insensitive G-proteins. J Pharmacol Sci 92:259-266

29. Holmqvist T, Johansson L, Ostman M, Ammoun S, Akerman KE, Kukkonen JP (2005) OX1 orexin receptors couple to adenylyl cyclase regulation via multiple mechanisms. J Biol Chem 280:6570-6579

30. Renstrom E, Eliasson L, Rorsman P (1997) Protein kinase Adependent and -independent stimulation of exocytosis by cAMP in mouse pancreatic $\beta$-cells. J Physiol 502:105-118

31. Kashima Y, Miki T, Shibasaki T et al (2001) Critical role of cAMPGEFII-Rim2 complex in incretin-potentiated insulin secretion. J Biol Chem 276:46046-46053

32. Arafat AM, Kaczmarek P, Skrzypski M et al (2014) Glucagon regulates orexin A secretion in humans and rodents. Diabetologia 57:2108-2116

33. Baranowska B, Wolinska-Witort E, Martynska L, Chmielowska M, Baranowska-Bik A (2005) Plasma orexin A, orexin B, leptin, neuropeptide Y (NPY) and insulin in obese women. Neuro Endocrinol lett 26:293-296 